\title{
EFFECTIVENESS NETWORK GOVERNANCE IN MAKING OF SPECIAL REGIONAL REGULATIONS IN PAPUA PROVINCE
}

\author{
Hamjah Bonso ${ }^{1}$, Suranto ${ }^{2}$ \\ ${ }^{1}$ Postgraduate Program of Government Science Universitas Muhammadiyah Yogyakarta \\ Yogyakarta, Indonesia \\ ${ }^{2}$ Lecture of Government Science Universitas Muhammadiyah Yogyakarta Yogyakarta, Indonesia

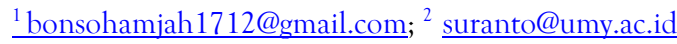

DOI: https://doi.org/10.18196/jgpp.53101

Article Info

Article history:

Received 09 Aug 2018

Revised 05 Nov 2018

Accepted 30 Nov 2018

Keywords:

Effectiveness, Governance

Network, Perdasus.

\section{ABSTRACT}

Abstract-Since the implementation of Special Autonomy law, the system of governance of Papua province experiencing changes in terms namely institutional establishment of the Papuan People's Assembly (MRP). The presence of MRP institutions greatly affect the implementation of the Provincial Government of Papua, especially in the manufacture of specific local regulations. The purpose of this study was to determine the effectiveness of the network between local governance institutions in the manufacture of specific local regulations (Perdasus) in Papua province. This study uses "triangulation" that combines qualitative and quantitative methods. The use of this method to produce a general overview of the phenomenon to be studied. In this study suggest that the making of specific local regulations (Perdasus) involving the three institutions namely the provincial government, the DPRP and MRP have done quite effectively. It is characterized by involvement, commitment, roles, and the implementation of mechanisms of each institution towards making Perdasus based authority. The study recommends that the need for institutional capacity development, especially against the MRP as a representative institution of the Papuan people.

\section{ABSTRAK}

Sejak pelaksanaan undang-undang Otonomi Khusus, sistem pemerintahan provinsi Papua mengalami perubahan dalam hal yaitu pembentukan kelembagaan Majelis Rakyat Papua (MRP). Kehadiran lembaga MRP sangat mempengaruhi pelaksanaan Pemerintah Provinsi Papua, terutama dalam pembuatan peraturan lokal yang spesifik. Tujuan dari penelitian ini adalah untuk menentukan efektivitas jaringan antara lembaga pemerintahan lokal dalam pembuatan peraturan lokal khusus (Perdasus) di provinsi Papua. Penelitian ini menggunakan "triangulasi" yang menggabungkan metode kualitatif dan kuantitatif. Penggunaan metode ini untuk menghasilkan gambaran umum dari fenomena yang akan dipelajari. Dalam penelitian ini menunjukkan bahwa pembuatan peraturan daerah 
spesifik (Perdasus) yang melibatkan tiga lembaga yaitu pemerintah provinsi, DPRP dan MRP telah dilakukan dengan cukup efektif. $\mathrm{Hal}$ ini ditandai dengan keterlibatan, komitmen, peran, dan pelaksanaan mekanisme dari masing-masing lembaga untuk membuat otoritas berbasis Perdasus. Studi ini merekomendasikan perlunya pengembangan kapasitas kelembagaan, khususnya terhadap MRP sebagai lembaga perwakilan masyarakat Papua

\section{INTRODUCTION}

Decentralization in Indonesia that is currently underway is a concrete manifestation of the principles of democracy that can not be withdrawn in the form of centralization. The political reforms that occurred in 1998 has mandated the various opportunities in deprogram in politics, and not the exception in the pattern of centerperiphery relations (Mallarangeng, 2006) [1]. The development dimension of democratization of local government to deliver the meaning of decentralization to the political approach (devolution) and administrative approach (deconcentration).

Policy administration decentralization and local autonomy in the reform period is stipulated in Law No. 22 of 1999, which was then revised by Act No. 32 of 2004 on Regional Autonomy. This policy brought real consequences to the administration of the autonomous rights of the wider and larger to local governments. This includes efforts to optimize the efficiency of the strategy in public service local level with reference to the principle of "local democracy". It is very important, given that democratic governments must put the interests of the people and do not require the concentration of state power 
over state institutions that perform the function of government, so as to materialize mechanism of the checks and balances.

Special autonomy was unknown in Indonesia state government system in the reform era. Officially special autonomy to be part of the system of state administration through second amendment to the 1945 Constitution, Chapter VI Regional Government Article 18 paragraph (1) which says: "the Republic of Indonesia is divided into upper areas of the province and the area was divided into districts and municipalities, that each province, district, and the city has a local government, which is regulated by Law ".

Papua regional administration after the enactment of Law No. 21, 2001 to change one of them in terms of local government institutions. Where government agencies Papua province, as set forth in Section $(\mathrm{V})$ on the shape and composition of government Article (5) of paragraph (1) says "The Regional Government of Papua Province comprises the Papuan Legislative Council (DPRP) as a legislative body, the Provincial Government as the body executive. Furthermore, paragraph (2) says "In the framework of the implementation of special autonomy in Papua province established Papuan People's Assembly (MRP), which is the cultural representation of indigenous Papuans who have certain authorities to protect the rights of the Papuan people, based on respect for local customs and culture, women's empowerment, and strengthening religious harmony. 
326 In the area of policy-making in the form of local regulations, these three agencies work together in accordance with authority has. Therefore, all three components of the agency is the main pillar of local government in implementing special autonomy in Papua province up to execute the mandate of Special Autonomy law namely the manufacture of specific local regulations (Perdasus). Papua Special Autonomy has lasted 16 years, but until now the implementation of special autonomy in various regions of existing policies capable of answering the demands of the people of Papua.

One of the problems that appear in the implementation of the special autonomy is the management of local government. In addition, the relationship between the stakeholders implementing the special autonomy, the Governor, DPRP and MRP also has not established effectively. The lack of such ineffectiveness often seen when addressing the policies that will be made is in the process of making / legislative drafting as a follow-up of the special autonomy law in Papua.

Based on the description above background, the problem in this research is: What is the effectiveness of network governance in the manufacture of specific local regulations in Papua Province 2016?

The purpose of this study was to describe and analyze to determine the effectiveness of governance network in the manufacture of specific local regulations (Perdasus) in Papua special autonomy in achieving its objectives. 
The theoretical benefits of this research are expected to be useful to add, expand and deepen the study of the science of government and contribute ideas for local government agencies in Papua province. The practical benefits of this research are expected to provide a recommendation as input material / input for local governments in particular in order to network governance Papua Province in Papua province region can be fulfilled effectively, so that the special autonomy not only be limited to the Papuan people's expectations.

As several previous studies that used as a reference for the study are (1) research Robert Arage (2006), entitled "Institutional Analysis and managerial At the Provincial Government of Papua". This study aims to determine how the preparation of the Provincial Government of Papua in the establishment of a device with a variety of factors as the basis for consideration of the establishment as well as the criteria as set forth in the PP 8 Year 2003 on Guidelines for the regional organization. In addition this study once conducted an assessment and evaluation of the implementation of PP 84 of 2000 in the Provincial Government. Implementation of the PP 84 Year 2000 on Guidelines for the implementation of the regional organization does not always lead to output and outcome. a positive With the issuance of PP 8 In 2003 the Provincial Government seeks to reorganize the local device to obtain the device to be able to answer the needs of the region, improving the efficiency of public services, the management system of good governance(good governance).(2) Research Decky D. 
328 Wona (2007), entitled"Apparatus Resources Development Strengthening Institutional Capacity In the Regional Development Planning Agency Papua Province". From the research results that the development of personnel resources in strengthening institutional capacity in Regional Development Planning Agency Papua Province can be performed well. The factors that influence the development of personnel resources in strengthening institutional capacity at the Regional Development Planning Agency Papua Province are: a) organization, b) Participation Apparatus, and c) Budget. (3) Research Terianus L. Safkaur (2011), entitled"Institutional Capacity Papua People's Assembly (MRP) As Representative Institutions Papua native culture". These results indicate, institutions Papua People's Assembly (MRP) in performing their duties and responsibilities mandated by some obstacles or barriers that often encountered include: (a) The existence of political attitudes half-hearted from the government, thereby weakening the performance of Papua People's Assembly (MRP) (b) There is a suspicion of government (shadow separatism), (c) the recruitment process specifically elements of indigenous nature of the selection of the lower levels, so laden with political dynamics and politics of money, (d) Even observer Papua, see MRP, institutions cultural still gray, so that the institutions set up intended as a forum fighting for the basic rights of indigenous people of Papua have not empowered either, (e) political intervention is very strong from the government, as seen in the establishment of the province of West 
Papua in the context of political interest Jakarta and (f) The establishment of the MRP of West Papua.

The theoretical framework of this study is the network to define governance network is a network of government can be seen as a combination of the structure of government, and with a storied relationship between the entity horizontally or vertically. Although there is no definition of network administration but can be interpreted as a form of cooperation among government agencies (Loi C. Sauvee, 2002) [2].

Furthermore Loi C. Sauvee adding that the network government consider the organizational design component allocation of decision rights and inter-organizational mechanism. Overall, network administration is the institutional structure whose role simultaneously to define a process for quick adjustments to collective action among autonomous entities through the establishment of the order personally and to design mechanisms (both contract and noncontract) which allows the assurance that the behavior of individual partners to follow the rules collectively.

Meanwhile, Mark and Rhodes (2006) [3] specifies that the network is an organization of self-government, inter-organizational networks. in addition, government networks can be defined as a set of institutions and institutional complex relationship defined by roles or social function. Furthermore, Mark and Rhodes (2006) says that the governance of the network proper administration institution explore 
by studying unity government that informs the actions of individuals involved in all kinds of regulatory practices.

Meanwhile, Jones, ddk (1997) [4] says that there are various definitions of various experts on government networks, such as network administration termed the organization's network, network forms of organization, and networks are interlinked. From these definitions, grouped in two main concepts namely; (1) patterns in the exchange interaction and relationships, and (2) the flow of resources between independent units.

Provan \& Kenis (2007) [5] says that network governance forms can be Categorized along two different dimensions:

First, governance network may or may not be brokered. A second distinction can be made regarding governance in brokered networks by focusing on Whether the network is governed or externally governed participant.

From the first dimension that has been offered above implies that on the one hand, the network can be fully controlled by the organization that consists of a network. Each organization will interact with other organizations to set up the network, resulting in a highly decentralized form. Things like this are often called shared governance. On the other hand, the network may be highly mediated / initiated, with some direct interaction between organizations.

The second dimension implies on the one hand, that the network participant can be arranged with either collectively by the members of the network itself or in the set together. On the other hand, a single 
network participants can take the role by leading the organization itself. External network settings can be set in a unique way that is network administrative organization (NAO), which means that the network can be established organizational administration voluntarily by members of the network as part of the process of tissue formation.

By looking at the different dimensions described above, further Provan \& Kenis (2007) split the network governance-participant into two forms of governed networks and network administrative organization. Both of these forms by Provan $\&$ Kenis excuse in the implementation of governmental network although it is recognized from each of these forms has specific strengths and weaknesses.

The first form is a participant-governed networks that are simplest and most common form in organizing government participants. This shape is governed by a network of their own with no governance entity. separate This form of government can be achieved formally, such as regular meetings of the representatives of the designated organizations, or more informally through ongoing efforts, but usually not coordinated from people who have an interest in the success of the network. On the one hand, the setting can be a decentralized network participants by involving most or all of the network members to interact relatively equal in the governance process. It was said as a joint governmental administration.

The second form is the network administrative organization. This form gives the basic idea that the existence of a separate administrative set up specifically to manage the network and its 
332 activities, although the network participants still interact with each other. In this case the network intermediary network administrative organization can play a key role in coordinating and maintaining the network.

An administrative network organization may be modest in scale form of government networks. So the network is often referred to as a facilitator / mediator governmental network. Forms of administrative organization network can be used as a mechanism to increase the legitimacy of the network to handle the unique and complex problems and reduce the complexity of the problem of government.

Table I. 1

Governance Form Network

\begin{tabular}{|l|l|}
\hline $\begin{array}{l}\text { Form Network } \\
\text { Governance }\end{array}$ & Network Governance Dimension \\
\hline $\begin{array}{l}\text { Network } \\
\text { Participant } \\
\text { Governed }\end{array}$ & $\begin{array}{l}\text { • Involvement of network organization } \\
\text { - Commitment network organization }\end{array}$ \\
\hline $\begin{array}{l}\text { Administrative } \\
\text { Network } \\
\text { organization }\end{array}$ & • Role of network organization \\
\hline
\end{tabular}

Source: Elaboration author of Provan and Kenis (2007).

By looking at some of the theoretical basis of the above, as indicated by Provan and Kenis (2007) to conclude that the effectiveness of network governance will be executed if the attention to both forms of network governance: participant-governed network and network administrative organization. 


\section{METHODS}

\section{A. Types of Research}

This study uses the method of "triangulation"is a method that combines qualitative and quantitative research by integrating analysis content quantitative with in-depth interview techniques. Triangulation strategy is the incorporation of qualitative and quantitative research methods to produce a more complete picture of the phenomenon to be studied (Kelle, 2001) [6].

\section{B. Research Sites}

This research was conducted in the province of Papua. The location of this study are set for their allegation that the process of implementation of special autonomy in the relationship between local government agencies have not been applied effectively. Determination of research location because of the gaps in implementation given that government institutions in the province as the main shaft that determines the effective implementation of special autonomy.

\section{Techniques Collection Data}

Interviews in this research environment of the Papua provincial governor's office, the DPRP and MRP. Interviews were conducted in each speaker which has been determined based on the criteria in accordance with the purpose of research. Meanwhile, the collection of data by distributing questionnaires as much as 20 questionnaires including the governor's office environment, especially the law firm of 7 respondents, as many as seven respondents DPRP and MRP as 
334 much as 6 respondents. While the data collection with the documentation of the data of the minutes of proceedings of the DPRP, the minutes of the hearing MRP, local regulations, government agencies performance accountability reports, and other data related to the research.

\section{Techniques Analysis Data}

Data analysis in this research that is by the way: First,collect data on each institutions associated with the research. Second, data reduction(reduction of data) the steps being taken in the process of selecting, simplifying, abstracting, and transforming raw data obtained from the field recently. Third,data presentation(displaydata)that any reduced data presented for analysis or temporary concluded. Fourth,conclusion / verification of the process of drawing conclusions by elaborating on the data obtained from interviews, questionnaires, and documentation.

\section{RESULTS AND DISCUSSION}

\section{A. Dimension Network Participant Involvement}

Effectiveness of network governance in achieving the objectives collectively can be influenced by the form of government networks. To that end, the network setting government made up of several institutions is necessary because there is no separate government entity. Governmental network settings interdependent exclusively on the involvement and commitment of the participants of the network. Each of these institutions into government network participants are 
responsible for managing the network of relationships, both internally and externally.

Network settings is the collectivity of government partners who make decisions(decision making) to manage the activities in the same network destination. Governmental network that forms of cooperation on network-level decisions, although there are differences in terms of size of organization, resource capacity, and performance. In the government as a partner network is no different, formal administrative entity of some administrative and coordination activities can be carried out by the network participants. This is because the network of participants to act collectively and no single entity on the network as a whole.

The implementation of a decentralized system that has implications for local authorities who adopt laws to regulate the provinces in particular. Since the adoption of Act No. 21 of 2001 on Special Autonomy in Papua, Papua provincial government implementation experience changes in terms of local governance institutions. Where the Papua provincial government agencies have three principal institutions in the management of government namely the Provincial Government (Provincial), DPRP and MRP. The third component of this government is the main pillar provincial government in implementing special autonomy in Papua province.

Setting the three pillars of involvement in the manufacture Perdasus born on the basis of the implementation of the Papua Special Autonomy Law. This indicates the involvement of the three 
33. pillars of responsibility that has been given by the central government to the regions in managing the region independently. Each of these pillars of this government has a responsibility in carrying out duties under the rules of the special autonomy law.

As it is known that specific local regulations (Perdasus) are regulations to be made. This is because, Perdasus a mandate or rules derived from legislation introduced in Papua special autonomy. For that purpose in manufacture Perdasus, provincial government involvement, DPRP and MRP are on the order of the authority is as shown in the following table:

Table III.1

Authority Based Institution

\begin{tabular}{|l|l|}
\hline Institution & authority \\
\hline $\begin{array}{l}\text { Regional of } \\
\text { Papua } \\
\text { Province }\end{array}$ & $\begin{array}{l}\text { - Create regional legislation program. } \\
\text { - Prepare draft local regulations. } \\
\text { - Initiate vertical institutions in making Propemperda. }\end{array}$ \\
\hline $\begin{array}{l}\text { Papuan } \\
\text { Legislative } \\
\text { Council }\end{array}$ & $\begin{array}{l}\text { - Prepare draft local regulations. } \\
\text { - Conducting discussions on the draft local regulations. } \\
\text { - Establish and certify local regulations. }\end{array}$ \\
\hline M RP & $\begin{array}{l}\text { - Giving consideration and approval of the draft Perdasus. } \\
\text { - Provide recommendations on the outcome of the } \\
\text { discussion Perdasus consideration and approval. }\end{array}$ \\
\hline
\end{tabular}

Source: Elaboration authors from various sources.

In the implementation of the decentralization policy requires that the central government gives local levels of government authority to regulate and manage the interests of the community. In connection with the decentralization policy, local governments have the force of law as stipulated in Law No. 32 of 2004 which was later converted 
into Law No. 23 of 2014 and Law No. 12 of 2011 on the establishment of legislation.

The provincial government of Papua and the DPRP in making Perdasus is necessary, as it has been mandated by the Papua Special Autonomy Law because Perdasus intended to regulate the rights of indigenous Papuans. It is the basis of local government in formulating policies in the form of regional regulations. With the authority of both institutions and their available resources, providing ease of local government to draft local regulations as shown in the table below:

Table III.2

Number RaperdasusBased Initiatives

\begin{tabular}{|c|c|}
\hline Raperdasus & Proposed \\
\hline Procedures for Election of M embers of M RP & \multirow{4}{*}{$\begin{array}{l}\text { Provincial } \\
\text { Governm } \\
\text { ent }\end{array}$} \\
\hline $\begin{array}{l}\text { Perdasus Amendment No. } 25 \text { Year } 2013 \text { concerning } \\
\text { Financial Management Admission DOK }\end{array}$ & \\
\hline $\begin{array}{l}\text { Perdasus Amendment No. } 6 \text { of } 2014 \text { on DPRP Membership } \\
\text { Appointment Mechanism established through the period } \\
2014 \text { to } 2019\end{array}$ & \\
\hline Mineral and Coal Mining Management & \\
\hline Papua Native & DPRP \\
\hline
\end{tabular}

Sources: $\quad$ Primary data is processed from the Minutes of the Plenary Meeting of the DPRP, 2016.

Result number Raperdasus which were initiated by the regional government of the province indicated that the performance and responsibilities of individuals who are at the level of the working environment of the provincial government has done well, it is then 
338 that clarified with the results of interviews with the Head of Regional Regulation of the Legal Bureau of Papua, which saysthat:

" Perdasus has become the authority and responsibility of the provincial governments ought to be. This responsibility is inseparable from the performance of any individual who is directly involved to make the Perdasus draft. It is recognized as Perdasus it more specifically to accommodate a bias against indigenous Papuans (OAP)."(Interview dated May 18, 2016, at 13:18 s / d 14:53)

Although DPRP have rulemaking authority in the area as it has been regulated by law, but the DPRP involvement in the drafting of Perdasus only in the discussion and determination. It is shown in the table above, where the draft Perdasus derived from DPRP initiative is only one design only.

DPRP involvement in the preparation of Perdasus indispensable. This is then clarified by data from interviews with the head of the DPRP BP3D saying that:

"Perdasus it comes from two sources, the first Perdasus DPRP and the second initiative Perdasus Executive initiative. The preparation or manufacture of any form of regulation either Perdasi and Perdasus must involve DPRP as through DPRP will be done either through a commission discussion, faction, or joint commission to look at the charge material. DPRP in making Perdasus very involved because Perdasus that regulate matters of the indigenous people of 
Papua, while DPRP representatives of the Papuan people themselves."(Interview dated May 12, 2016, 13:03 hours s / d 14:49)

As a public representative institutions Papua, MRP agency has the authority in terms of governance. MRP authority is seen in its involvement in the manufacturing of local regulations, as stipulated in Law No. 21 of 2001 states that the MRP is entitled to consideration and approval to Perdasus created and defined by the DPRP together governor. Implementation of the consideration and approval by the MRP was reaffirmed in Article 29, paragraph 3 states the procedures for granting consideration and approval of the MRP set in Perdasi.

MRP involvement in giving consideration and approval Perdasus manufacture set back by Perdasus No. 3 of 2008 on the implementation of the rights and obligations of the involvement MRP.Selain MRP set also in Perdasus No. 4 of 2008 regarding the duties and authority of the MRP. In Article 8 Perdasus No. 42008 said DPRP submitted a draft Perdasus results of the discussion the Governor and DPRP to the MRP for consideration and approval.

As a partner of the provincial local governance institutions in implementing special autonomy in Papua, MRP is an integral part or a whole of the DPRP and the Governor who have the same degree in making decisions(decision making). To that end, the involvement of MRP in giving consideration and approval to Raperdasus very important, which is then made clear from the interview with the Chairman of MRP which says that: 
"With this legislation Papua Special Autonomy have consequences for the establishment of the Papuan People's Assembly (MRP), MRP here has a rights and authority as cultural institutions and state agencies in the area regulated by law and local regulations provinsi.Kami MRP environment, in terms of providing consideration and approval Raperdasus always refer to the legislation and we have to run it because it involves the rights Papuans, as representative of the people of Papua.(Interview dated May 23, 2016, 09:03 hours $s / d$ 10:45)

\section{Table III.3}

The Participation of MRP

\begin{tabular}{|l|l|l|l|}
\hline \multirow{2}{*}{ Session Agenda } & $\begin{array}{l}\text { Member } \\
\text { Number } \\
\text { M RP }\end{array}$ & \multicolumn{2}{|l|}{ Prencentation } \\
\cline { 2 - 4 } & Attending & $\begin{array}{l}\text { Not } \\
\text { Atten } \\
\text { ding }\end{array}$ & \\
\hline Papua native. & 37 & 5 & $88 \%$ \\
\hline $\begin{array}{l}\text { Procedures for Election of Members } \\
\text { of the MRP. }\end{array}$ & 34 & 8 & $80 \%$ \\
\hline $\begin{array}{l}\text { Change Perdasus No. 25 Year 2013 } \\
\text { concerning Financial Management } \\
\text { Admission SAF. }\end{array}$ & 39 & 3 & $92 \%$ \\
\hline $\begin{array}{l}\text { Changes Perdasus No. 6 of 2014 on } \\
\text { DPRP Membership Appointment } \\
\text { Mechanism established through the } \\
\text { period 2014-2019. }\end{array}$ & 28 & 14 & $66 \%$ \\
\hline $\begin{array}{l}\text { Management of Mineral and Coal } \\
\text { Mining. }\end{array}$ & 31 & 11 & $73 \%$ \\
\hline
\end{tabular}


Source: $\quad$ Primary data is processed from the Minutes of the hearing MRP,2016.

The following table describes the three branches of government involvement in the preparation of Papua province/manufacture Perdasus obtained from respondents.

Table III.4

Respondents on the Involvement of

\begin{tabular}{|c|c|c|c|c|c|c|c|c|}
\hline \multirow[t]{3}{*}{ Institutions } & \multicolumn{6}{|c|}{ Answer } & \multirow{2}{*}{\multicolumn{2}{|c|}{ Number }} \\
\hline & \multicolumn{2}{|c|}{ Yes } & \multicolumn{2}{|c|}{ Neutral } & \multicolumn{2}{|c|}{ No } & & \\
\hline & $f$ & $\%$ & $f$ & $\%$ & $f$ & $\%$ & $f$ & $\%$ \\
\hline $\begin{array}{l}\text { Provincial } \\
\text { Government }\end{array}$ & 5 & 25 & 0 & 0 & 2 & 10 & 7 & 35 \\
\hline DPRP & 4 & 20 & 1 & 5 & 2 & 10 & 7 & 35 \\
\hline MRP & 3 & 15 & 0 & 0 & 3 & 15 & 6 & 30 \\
\hline Total & 12 & 60 & 1 & 5 & 7 & 35 & 20 & 100 \\
\hline
\end{tabular}

Source: Data compiled from questionnaires

The table above signify the total of 12 respondents (60\%) that the three branches of the regional administration was heavily involved in the drafting of local regulations by authorities. A total of seven respondents (35\%) chose not because DPRP institutions only involved in the discussion and endorsement Perdasus, while the MRP institutions only involved in granting approval and consideration as tasks and functions. However, MRP institutions in the process of giving consideration and approval to Perdasus has been implemented to the maximum. 


\section{B. Dimension Commitments Network Participant}

Commitments organizations is an attempt to define and involve themselves in the organization and there is no desire leave. Organizational commitment refers to identification with the goals of the organization, the ability to direct everything in its power for the benefit of the organization, and their interest to remain part of the organization. Formulating local regulations in the form of legislation it is possible to see the commitment of the governance carried out by local government agencies.

Commitment of the provincial government of Papua span the 'hierarchy of results of interviews conducted with one of the officials of the Legal Bureau of the Province as saying that:

"The commitment of the provincial government of Papua in this case the governor stuck with Papuans are preferred, although people say that the policy is made not mandated the Special Autonomy law or otherwise but in fact the policy of always referring to Autonomy statute and law establishing legislation."(Interview dated May 18, 2016, at $13: 18 \mathrm{~s} / \mathrm{d} 14: 53 \mathrm{CET}$ )

in addition to the results from the interview above, the Papua provincial government commitment is also evident from some Perdasus products that have been produced since legislation implemented Autonomy in Papua. Perdasus products can be seen in the image below: 


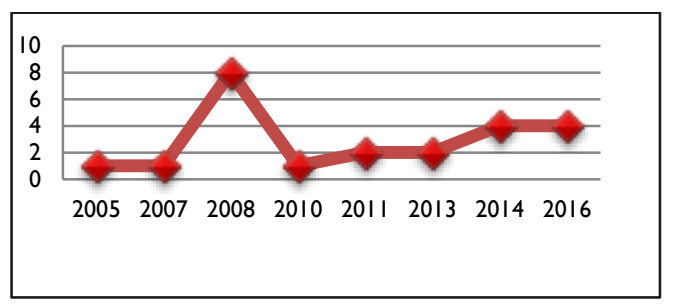

Figure III.1. Product Perdasus Papua Provincial Government 2005-2016

DPRP in the preparation / manufacture perdasus besides referring to Law No. 23 of 2014 on local government and Law No. 21 of 2001 on Special Autonomy, perpedoman also in Act No. 12 of 2011 on the establishment of legislation and Perdasi No. 9 of 2010 on the establishment of Perdasi and Perdasus. In Article 56 (Act No. 12 of 2011) said that the preparation in the form of draft provincial regulations can be derived from provincial assembly or governor.

DPRP as one of the institutions of the regional administration authority in the process of preparing / formulating local regulations. In Permendagri 802015 Article 33 states that the draft provincial regulations originating from the province DRPD may be submitted by members of the provincial parliament, commissions, joint commissions, or Bapemperda based Propemperda provinces. With reference of the Regulation, the commitment of DPRP in the preparation Perdasus indispensable. This is then clarified by data from interviews with the head of the DPRP BP3D saying that: 
37. "DPRP as the representative of the people of Papua must of course always ready to escort the form of regulation especially as a late Perdasus mandate of the special autonomy law. To that end, the DPRP very enthusiastic in the preparation / manufacture Perdasus because Perdasus that regulate matters of the Papuan people. This enthusiastic DPRP embodied in the spirit of the discussions conducted Raperdasus DPRP environment."(Interviewdated May 12, 2016, 13:03 hours s / d 14:49)

In addition to the results of interviews conducted with informants environment DPRP, DPRP commitment in the preparation / and ratification Perdasus can be seen also in the table below:

Table III.5

Presentation Presence In Discussion / Approval of the local budget, Raperdasusdan Raperdasi

\begin{tabular}{|c|c|c|c|}
\hline \multirow{2}{*}{$\begin{array}{l}\text { Plenary } \\
\text { Session } \\
\text { of }\end{array}$} & \multicolumn{2}{|c|}{ Member Number DPRP } & \multirow[t]{2}{*}{ Plenary M eeting Agenda } \\
\hline & Attending & $\begin{array}{l}\text { Not } \\
\text { Attending }\end{array}$ & \\
\hline $\begin{array}{l}\text { Plenary } \\
1\end{array}$ & 40 & 15 & Opening \\
\hline $\begin{array}{l}\text { Plenary } \\
2\end{array}$ & 44 & 11 & Overview of fractions. \\
\hline $\begin{array}{l}\text { Plenary } \\
3\end{array}$ & 44 & 11 & $\begin{array}{l}\text { Comments on Governor General } \\
\text { Overview Factions. }\end{array}$ \\
\hline $\begin{array}{l}\text { Plenary } \\
4\end{array}$ & 44 & 11 & $\begin{array}{l}\text { Submission of Reports and } \\
\text { Statements budget Agency } \\
\text { Formation Agency Regulation of } \\
\text { the provinces, a special local } \\
\text { regulation. }\end{array}$ \\
\hline Plenary- & 46 & 9 & Submission of reports of \\
\hline
\end{tabular}




\begin{tabular}{|l|l|l|l|}
\hline 5 & & 17 & Commissions. \\
\hline $\begin{array}{l}\text { Plenary } \\
6\end{array}$ & 38 & $\begin{array}{l}\text { Submission of Final Opinion } \\
\text { fractions. }\end{array}$ \\
\hline $\begin{array}{l}\text { Plenary } \\
7\end{array}$ & 48 & 7 & $\begin{array}{l}\text { Determination RAPBD 2016 and } \\
\text { Regulation of the provinces, a } \\
\text { special local regulation. }\end{array}$ \\
\hline
\end{tabular}

Sources:Primary data is processed on the M inutes of M eeting of the DPRP 2015

As a representative institution people of Papua, MRP agency has the authority in terms of governance. MRP authority is seen in its involvement in the manufacturing of local regulations, as stipulated in Law No. 21 of 2001 states that the MRP is entitled to consideration and approval to Perdasus created and defined by the DPRP together governor. Implementation of the consideration and approval by the MRP was reaffirmed in Article 29, paragraph 3 states the procedures for granting consideration and approval of the MRP set in Perdasi.

If you look at the authority possessed by the MRP, then make the MRP institutions involved in governance of Papua province. Therefore, the existence of the MRP will be indispensable in sustaining the local government of Papua to the formation / manufacture Perdasus. If this is not done, the mandate in Act No. 21 2001 was not implemented baik.Oleh Therefore, MRP commitment in carrying out its duties and authorities is indispensable in order to produce local regulations that are specific to the achievement of special autonomy in Papua. 
34. MRP implementation of the tasks and authority in local governance specifically towards the manufacture / preparation Perdasus then made clear from the interview with the Chairman of MRP which says that:

"We are members of the MRP that as many as 42 people in the line of duty and authority always refer to the laws Otsus.Selain it also, on the products of local regulations and other regulations relating to the authority of the MRP. And we must do these things because if it is not implemented, then we will get a warning from the central government. On the other hand, if it is not implemented means we failed to become a member of the MRP which has been entrusted by the people of Papua."(Interview dated May 23, 2016, 09:03 hours s /d 10:45)

MRP commitment in carrying out its duties and authorities to give consideration and approval of the draft Perdasus can be seen in the table below:

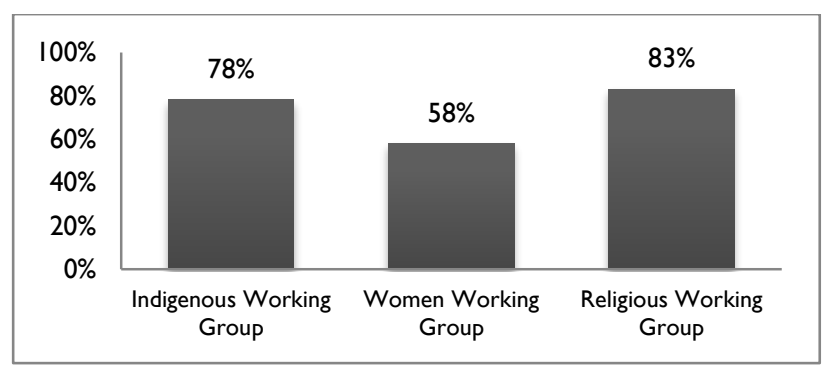

Figure III.2: Attendance of MRP Giving Consideration and Approval Raperdasus 
The following table describes the three branches of government commitment Papua province in the preparation / manufacture Perdasus obtained from respondents.

\section{Table III. 6}

Response Respondents aboutCommitment

\begin{tabular}{|c|c|c|c|c|c|c|c|c|}
\hline \multirow[t]{3}{*}{ Institutions } & \multicolumn{6}{|c|}{ Answer } & \multirow{2}{*}{\multicolumn{2}{|c|}{ Number }} \\
\hline & \multicolumn{2}{|c|}{ Yes } & \multicolumn{2}{|c|}{ Neutral } & \multicolumn{2}{|c|}{ No } & & \\
\hline & $f$ & $\%$ & $f$ & $\%$ & $f$ & $\%$ & $f$ & $\%$ \\
\hline $\begin{array}{l}\text { Provincial } \\
\text { Government }\end{array}$ & 6 & 30 & 1 & 5 & 0 & 0 & 7 & 35 \\
\hline DPRP & 3 & 15 & 0 & 0 & 4 & 20 & 7 & 35 \\
\hline MRP & 4 & 20 & 0 & 0 & 2 & 10 & 6 & 30 \\
\hline Total & 13 & 65 & 1 & 5 & 6 & 30 & 20 & 100 \\
\hline
\end{tabular}

Source: Data compiled from questionnaires

The table above signify the total 13 respondents (65\%) that the three branches of the regional administration is committed in the drafting of local regulations, this is because if one of the institutions do not commit the manufacture Perdasus will not legitimacy. A total of 6 respondents (30\%) stated that the intensity of the commitment by the DPRP in just in the process of discussions and ratification of the draft Perdasus. It also suggests that low levels of awareness and responsibility of members of the DPRP institutions in developing / designing the products of local regulations. While the MRP institutions have limited authority in terms of making Perdasus.

\section{Dimension Role of Participants Network}


348 Networkgovernmental organizations have an important role in organizational life. Network organization in the role of government functioning as intermediaries and ensure the rule running properly. In this regard, government will issue rules that will affect the life of the organization for a common goal. Where every organization in establishing cooperation with other organizations, acting managing their authority and establish coordination between the organization's network.

Papua provincial government's role in the creation / drafting local regulations pertaining to the function of legislation implementing the tasks that have been mandated in Permendagri 802015 Article 11 states that the Governor as the regional head of provincial government commissioned a regional leader in the preparation device in the environment Propemperda provincial government. Further, article 12, the preparation Propemperda environment is coordinated by the provincial government in charge of local devices provincial law.

Implementation of the provincial government's role in the government as a form of tissue in the area of law product makers is crucial for the formation of local regulations. These roles are then clarified based on interviews with the Head of Legal Bureau Regional Regulation Papua Province as saying that:

"The role of provincial governments still do Perdasus drafting legislation mandated by the Autonomy through the proponent agency. The provincial government has always accommodate to 
Raperdasus originating from the device area. For example, educational institutions propose Perdasus for remote indigenous communication (KAT), so the provincial government has always viewed the proposal not to conflict with other rules and regulations and there will be discrimination against the life of society in general. So the role of the provincial government is very large, with no government in this province ranked Governor process of preparation / manufacture Perdasus could not have happened, most Perdasus proposed from the provincial government."(Interviewdated May 18, 2016, at 13:18 s/d 14:53)

the role of provincial governments in the preparation /manufacture Perdasus through the preparation Propemperda involving vertical agencies who held government affairs in the field of law is always encouraging to always play a role and uphold the implementation of the legislation and other regulations binding.

In addition to the implementation of Law No. 23 In 2014, the role of DPRP in the creation / formation Perdasus stipulated in Law No. 21, 2001 article 7 which states that the DPRP has the duty and authority to discuss and set design and Perdasi Perdasus together governor. Furthermore, regulation of DPRP No. 1 of 2014 on the order of parliaments of each member DPRP Papua states have the right to propose draft Perdasi and Perdasus (Article 55).

One role of DPRP in the manufacturing / formulation of regional regulations and the establishment of the discussions on the draft regulations have been included in the list of the agenda of the plenary 
361 session. Here is the number of draft Perdasi and Perdasus set by the institution of the DPRP.

Table III.7

Total Raperdasi and Raperdasus Assigned

\begin{tabular}{|c|c|c|c|c|}
\hline \multirow{2}{*}{ Draft } & \multirow{2}{*}{ Set } & \multicolumn{2}{|c|}{ DPRP Number of M embers } & \multirow{2}{*}{$\begin{array}{c}\text { Presentatin } \\
\text { Attendance }\end{array}$} \\
\cline { 3 - 4 } & & Attending & Not Attending & \\
\hline $\begin{array}{c}12 \\
\text { Raperdasi }\end{array}$ & $\begin{array}{c}11 \\
\text { Perdasi }\end{array}$ & 38 & 17 & $69 \%$ \\
\hline $\begin{array}{c}5 \\
\text { Raperdasus }\end{array}$ & $\begin{array}{c}4 \\
\text { Perdasus }\end{array}$ & 49 & 6 & $89 \%$ \\
\hline
\end{tabular}

Source: $\quad$ Primary data is processed on the Minutes of M eeting of the DPRP 2016

DPRP as one of the institutions of the regional administration authority in the process of preparing / formulating local regulations. In Permendagri 802015 Article 33 states that the draft provincial regulations originating from the province DRPD may be submitted by members of the provincial parliament, commissions, joint commissions, or Bapemperda based Propemperda provinces. This is then clarified by data from interviews with the head of BP3D DPRP as saying that:

"Bapemperda DPRP in a discussion of the Raperdasus were initiated by the DPRP, on the initiative of the board that make up or make then convened to do determination Raperdasus before it is submitted to the government province. Raperdasus drafting done by the DPRP refers to the rules implemented by BP3D, if this has been agreed in Raperdasus Bapemperda environment it will be included 
in the list of programs of local legislation to be discussed in the plenary session."(Interview dated May 12, 2016, 13:03 hours s / d $14: 49)$

The presence of MRP in addition has the duty and authority to give consideration and approval, MRP also has rights and obligations that must be implemented. This was stated in Perdasus No. 3 of 2008 on the implementation of the rights and obligations of the MRP. Furthermore, in Article 2 on the MRP rights states that:

a. Request information from the provincial, regency /municipality on matters related to the protection of the rights OAP;

b. Requesting reconsideration or regulation Perdasi governor considered contrary to the protection of the rights of OAP.

Implementation of duties and authority of MRP in local governance in particular to the manufacture / preparation Perdasus then made clear from the interview with the Chairman of MRP which says that:

"The authority of the MRP as one of the institutions of local governance on par with the provincial government and the DPRP has duties including providing consideration and approval to Perdasus. Here, the role of the MRP has mandated the special autonomy law. As an agency of the regional administration and as a partner who has the duty and authority to the formation Perdasus, then our MRP environment should remain the task and authority."(Interview dated May 23, 2016, 09:03 hours s / d 10:45) 
MRP in carrying out its duties and authorities to give consideration and approval of the draft Perdasus can be seen in the table below:

Table III. 8

Giving Considerations and Persejutuan Raperdasus

\begin{tabular}{|c|c|}
\hline Perdasus & Recommendations deal \\
\hline $\begin{array}{l}\text { Specialized Financial } \\
\text { Management in } \\
\text { Papua }\end{array}$ & $\begin{array}{l}\text { province-specificpolicies need to be set in the } \\
\text { shopping areas of specialized financial } \\
\text { management regulations Papua province. } \\
\text { However, it is expected that financial management } \\
\text { transparency, responsibly, and with regard to the } \\
\text { principle of justice as well as beneficial to society } \\
\text { and strengthening of indigenous Papuans. }\end{array}$ \\
\hline $\begin{array}{l}\text { Changes Perdasus } \\
\text { No. } 6 \text { of } 2014 \\
\text { concerning } \\
\text { Membership DPRP } \\
\text { determined through } \\
\text { the period 2014- } \\
\text { 2019Appointment } \\
\text { Mechanism }\end{array}$ & $\begin{array}{l}\text { MembershipDPRP through areas appointment } \\
\text { needs to be done to accommodate the } \\
\text { participation of indigenous Papuans in the } \\
\text { aspirations in the process of implementation of } \\
\text { regional development. }\end{array}$ \\
\hline $\begin{array}{l}\text { Management of } \\
\text { Mineral and Coal } \\
\text { Mining }\end{array}$ & $\begin{array}{l}\text { Wealth of natural resources in the province is very } \\
\text { large, it is necessary to set the management } \\
\text { optimally in the interest of the welfare of the } \\
\text { people at the present time to be coming fairly and } \\
\text { would have to take into consideration the } \\
\text { continuity of the welfare of society in general and } \\
\text { more specifically for the benefit of native Papuans } \\
\text { (OAP) }\end{array}$ \\
\hline $\begin{array}{l}\text { Changes Perdasus } \\
\text { No. } 25 \text { Year } 2013 \\
\text { concerning Financial } \\
\text { Management } \\
\text { Admission DOK }\end{array}$ & $\begin{array}{l}\text { Need for construction of public housing habitable } \\
\text { for OAP, given the Papuan people who are in } \\
\text { remote areas with limited economy is still far from } \\
\text { prosperity. What else DOK was designated in the } \\
\text { field of education, health, economy, and }\end{array}$ \\
\hline
\end{tabular}


infrastructure.

Source: primary data from the M inutes of M eeting of the M RP.

Implementation of duties and authority of MRP agencies in giving consideration and approval to Raperdasus can be said to be performing well, it is characterized by the level of participation of its members to the administration Perdasus consideration and approval. On the other hand, MRP institutions realize the duties and authority should be implemented as a form of accountability against indigenous Papuans and realize that the presence of MRP to consider the interests of the rights of indigenous Papuans. It is also recognized by every member of the MRP agency that the presence of those who gathered in the center to give consideration and approval to the formation of Perdasus is necessary, because if it does not approve the MRP shall be deemed invalid Perdasus. Sehingganya regulations to accommodate the interests of indigenous Papuans did not materialize.

The following table describes the three branches of government's role in the preparation of Papua province / manufacture Perdasus obtained from respondents.

Table III.9

Reseponse Respondents about Role theofthe answer Total 


\begin{tabular}{|c|c|c|c|c|c|c|c|c|}
\hline \multirow{2}{*}{} & \multicolumn{2}{|c|}{ Yes } & \multicolumn{2}{|c|}{ Neutral } & \multicolumn{2}{c|}{ No } & \multicolumn{2}{|c|}{} \\
\cline { 2 - 9 } & $\mathrm{f}$ & $\%$ & $\mathrm{f}$ & $\%$ & $\mathrm{f}$ & $\%$ & $\mathrm{f}$ & $\%$ \\
\hline $\begin{array}{c}\text { Provincial } \\
\text { Government }\end{array}$ & 4 & 20 & 1 & 5 & 2 & 10 & 7 & 35 \\
\hline DPRP & 3 & 15 & 0 & 0 & 4 & 20 & 7 & 35 \\
\hline MRP & 4 & 20 & 0 & 0 & 2 & 10 & 6 & 30 \\
\hline total & 11 & 55 & 1 & 5 & 8 & 40 & 20 & 100 \\
\hline
\end{tabular}

Source: Data compiled from questionnaires.

The table above signify the total of 11 respondents (55\%) that the three branches of the regional administration was instrumental in the drafting of local regulations, this is because if between one of the three institutions did not perform its role can not be determined then Raperdasus be Perdasus. A total of 8 respondents (40\%) stated that the lack of role DPRP institutions due to lack of responsibility of parliamentarians to draft Perdasus, so just be on the discussion and endorsement. While the MRP agencies in making Perdasus only be at the level to give consideration and approval.

\section{Dimension Mechanism Network Participants}

Mechanism as a form of network organization administration was instrumental in establishing cooperation between governmental administration. Governance can not be separated from the organization in implementing the mechanism of administrative 
system and set the course of the organization. Organizational network mechanisms regulate the interaction between the organization with other organizations on the implementation of the whole system to generate activities to achieve goals.

Mechanism preparation / drafting of local regulations do provincial government environment refers to the legislation. In addition, the provincial government also refers to local regulations as the derivative regulations Perdasi No. 9 of 2010 on the establishment of Perdasi and Perdasus. It is then clarified based on interviews with the Head of Regional Regulation of the Legal Bureau of Papua Province as saying that:

"If we talk mechanism preparation / drafting of local regulations do not vary much by a mechanism made by other regions and of course we in this case the provincial government has always followed rules governing the manufacture of products of local regulations, for example: Law and regulation related to the mechanism of the regulation. In addition, in the province alone there are rules that govern the preparation / rulemaking and we as implementers of government must continue to implement the regulation, be it law, Regulation or local regulations because if not, then we would violate the conditions set."(Interview dated May 18, 2016, at 13:18 s/d 14:53)

DPRP Institutions related to rulemaking area, not only based on Law No. 23 of 2014 on local government and Law No. 21 of 2001 on Special Autonomy, but perpedoman also in Act No. 12 of 2011 on the establishment of legislation and Perdasi No. 9 of 2010 on the establishment of Perdasi and Perdasus. In Article 56 (Act No. 12 
356 of 2011) said that the preparation in the form of draft provincial regulations can be derived from provincial assembly or governor.

In Permendagri 802015 Article 33 states that the draft provincial regulations originating from the province DRPD may be submitted by members of the provincial parliament, commissions, joint commissions, or Bapemperda based Prolegda provinsi.Selain it is also, in the regulation of DPRP No. 1 of 2014 about the Rules of Conduct DPRP every member has a right as mentioned in article 11 which states the right of parliamentarians or the right to submit a draft Perdasi and Perdasus. Mechanism preparation / drafting of local regulations in the environment DPRP explained by the chairman BP3D DPRP as saying that:

"The design perdasus on the initiative by the DPRP come from members of the DPRP either personally or as a group, and then submitted to BP3D to be reviewed and harmonized in order not contrary to the legislation and there is no negative impact on the implementation of the regulation when it is established or authorized."(Interview dated May 12, 2016, 13:03 hours s / $d$ 14:49)

the mechanism of preparation / creation of local laws that do DPRP environment can be seen clearly in the picture below:

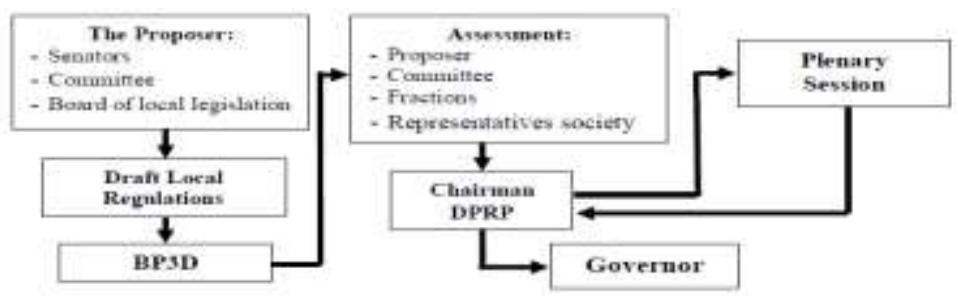

Source:Elaboration writer based Perdasi No. 92010

Figure III.3. Mechanism preparation / drafting of local regulations DPRP institutions. 
MRP institutions who attended as a representative institution of culture Papuan society has no authority in the preparation / drafting of local regulations especially on specific local regulations (Perdasus) as mandated by law and regulations. That is, the MRP agencies are not directly involved either independently or do not have the right legislation in preparation / manufacture Perdasus.

Implementation of duties and authority as a representative institution of society MRP Papuan culture in governance of Papua province, especially for the preparation / drafting of local regulations governed by Perdasus No. 3 of 2008 on the implementation of the rights and obligations of the MRP. Additionally MRP agency to carry out its duties and authorities set also in Perdasus No. 4 in 2008. It then made clear from the interview with the Chairman of MRP which says that:

"Papua People's Assembly (MRP) mastermind authority concerned with the rights of indigenous Papuans, especially in terms of regulation. Products such regulations drawn up by the executive Perdasus submitted to DPRP, and before it was passed segerah submitted to the MRP to learn / study. Thus, the authority of MRP in the manufacture of products of local regulations only give consideration and approval to Perdasus.MRP to give consideration and approval conducted internal discussions and assessment in the working group, after it and then send to plenary session together elements of leadership MRP environment. In the plenary meeting will be submitted Raperdasus reasons whether they were approved to amend the clauses and written recommendations regarding the changes."(Interview dated May 23, 2016, 09:03 hours s / d 10:45) 
mechanism for consideration and approval of the draft Perdasus conducted by the MRP can be seen clearly in the picture below:

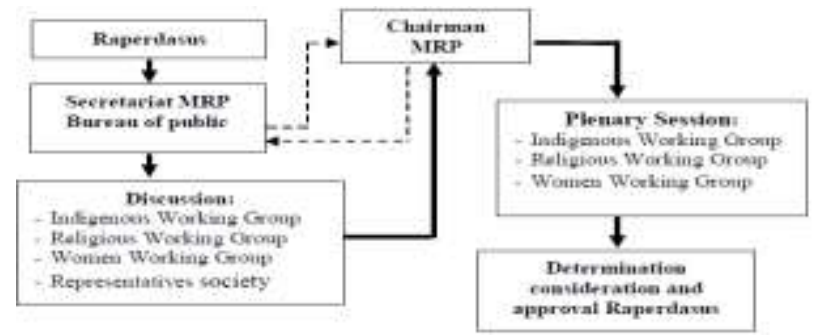

Source: elaboration of the author based Perdasus No. 4 of 2008 and No. 200454

Figure III.4. The mechanism giving consideration and approval Raperdasus MRP institutions.

The following table illustrates the implementation mechanism of the three branches of government of Papua province in the preparation / manufacture Perdasus obtained from respondents.

Table III.11

Respondents on Implementation Mechanism Perdasus Making

\begin{tabular}{|c|c|c|c|c|c|c|c|c|}
\hline \multirow[t]{3}{*}{ Institutions } & \multicolumn{6}{|c|}{ Answer } & \multicolumn{2}{|c|}{ Number } \\
\hline & \multicolumn{2}{|c|}{ Yes } & \multicolumn{2}{|c|}{ Neutral } & \multicolumn{2}{|c|}{ No } & & \\
\hline & $f$ & $\%$ & $f$ & $\%$ & $f$ & & $f$ & $\%$ \\
\hline $\begin{array}{l}\text { Provincial } \\
\text { Government }\end{array}$ & 6 & 30 & 1 & 5 & 0 & 0 & 7 & 35 \\
\hline DPRP & 6 & 30 & 1 & 5 & 0 & 0 & 7 & 35 \\
\hline M RP & 5 & 25 & 1 & 5 & 0 & 0 & 6 & 30 \\
\hline Total & 17 & 85 & 3 & 15 & 0 & 0 & 20 & 100 \\
\hline
\end{tabular}

Source: Data compiled from questionnaires

The table above signify the total of 17 respondents (85\%) that the three branches of government administrators in making local regulations have been made under the provisions in force. This is 
because the level of understanding and experience of the regional administration of the province in the manufacture/ preparation of the draft local regulations, although the implementation of the mechanism of Perdasus based with the competencies of each institution. While three respondents (15\%) chose not to answer because not understand clearly related to the implementation of the mechanism in the making Perdasus.

\section{CONCLUSION}

The effectiveness of network governance law making visible areas of the network setting organization that focuses on the involvement and commitment of each institution. On the dimension of engagement, provincial governments dominate Perdasus manufacture, it is seen from the number of Raperdasus proposed. Meanwhile, the DPRP's involvement was minimal participation to the creation/preparation Perdasus, due to apathy and work responsibilities as elected representatives. While MRP duties and responsibilities based on the authority that had. On the commitment side, seen that the three branches of the regional administration is very committed to the manufacture of specific local regulations. Meanwhile, the effectiveness of network governance in terms of the role shows that the three institutions is a decisive factor formation of a regional regulation. Implementation in the manufacture Perdasus mechanism has been implemented in accordance with the provisions governing each institution. Of the various dimensions of network governance network of cooperation between the provincial government to coordinate with each other DPRP institution about the rules that will be discussed and ratified. 
361 While the relationship between the institution of the DPRP with MRP to coordinate the draft Perdasus order to get consideration and approval before it is set to be Perdasus

\section{REFERENCES}

Mallarangeng, A. Andi (2006). Blue Print: Otonomi Daerah Indonesia. Ed. 1, Jakarta: Yayasan Harkat Bangsa.

Sauvee, Loi C. (2002). Efficiency, Effectiveness and the Design of Network Governance. Jurnal dipublikan di International Conference on Chain Management in Agribusiness and the Food Industry Noordwijk an Zee. Oficina PENSA.

Bevir, M ark. And Rhodes. R.A.W. (2006). Decentred Theory, Change and Network Governance. Di publikasikan pada eScholarship UC: Theories of Democratic Network Governance.

Jones, Candace. Dkk (1997). A General Theory of Network Gvernance: Exchange Conditions and Social Mechanisms. Jurnal Academy of management, dipublikasikan pada JSTOR 2010.

Provan, Keith. G, and Kenis, Patrick (2007). Modes of Network Governance: Structure, Management, and Effectiveness. Journal of Public Administration Research and Theory, Oxford University Press.

Kelle, Udo. (2001). Sociological Explanation Between Micro and Macro and the Integration of Qualitative and Quantitative Methods. Jurnal: Forum Qualitative Social Research. Vol. 2 No. 1, Februari 2001. 